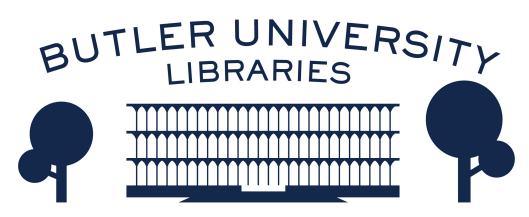

Journal of Hindu-Christian Studies

Volume 10

Article 12

January 1997

\title{
Viewpoints: Hindu-Christian Dialogue During the Past Decade
}

S. Wesley Ariarajah

Follow this and additional works at: https://digitalcommons.butler.edu/jhcs

Part of the Religion Commons

\section{Recommended Citation}

Ariarajah, S. Wesley (1997) "Viewpoints: Hindu-Christian Dialogue During the Past Decade," Journal of Hindu-Christian Studies: Vol. 10, Article 12.

Available at: https://doi.org/10.7825/2164-6279.1158

The Journal of Hindu-Christian Studies is a publication of the Society for Hindu-Christian Studies. The digital version is made available by Digital Commons @ Butler University. For questions about the Journal or the Society, please contact cbauman@butler.edu. For more information about Digital Commons @ Butler University, please contact digitalscholarship@butler.edu. 
personal choice of the painter is involved. Secondly, even those who do not welcome the presence of Christian missionaries in India do acknowledge the commitment, the courage, and personality of these missionaries.

Similar to what happens among the Christian communities, there is also a ferment at work among the Hindus. The Christian presence does provoke them. It could be expressed in many ways - in anger and resentment, denying the equality to the Christian dalits, refuting the Christian claims in some form or other in their publications, citing the Christian example to motivate or correct their own community and so on. There are also positive words of appreciation for what the Christians do. But then this is not mainly due to the Hindu-
Christian dialogue initiative as we understand it today. One must admit that it is more the historical necessity of the present-day socio-political situation in India, in which no community can claim to achieve self-sufficiency or security all by itself without recourse to and interaction with other communities around. Various factors are at work to bring about this attitude.

So one cannot measure the HinduChristian dialogue in terms of numbers (of meetings, publications, or subscriptions to related journals) but by perceiving the growing awareness of one another's presence in public life; and the challenge it offers to re-think about one's own religious tradition with reference to others is already a great achievement.

\title{
Hindu-Christian Dialogue During the Past Decade
}

\author{
S. Wesley Ariarajah \\ World Council of Churches, Geneva
}

PERHAPS IT IS not too much of an exaggeration to claim that future historians will consider the past decade to be one of the most crucial periods in the development of contemporary Hinduism, both in its native Indian subcontinent and in other parts of the world. In India itself, the expression of the collective Hindu political consciousness has never been more articulate and the goal of making India a "Hindu Nation" never before seemed a reality within reach. Even many Hindu intellectuals who keep close watch on the tenuous relationship between religion and politics in a multifaith India were taken by surprise at the energy the concept of "Hindutva" has been able to generate, an energy that was strong enough to pull down the mosque at Ayodhya, and with it some of the reputation Hinduism has enjoyed in the West as one of the most tolerant religions of the world.

Equally dramatic developments have also taken place in nations like Fiji and Trinidad where Hindus had settled down during the colonial period. In Fiji the rise of the Fijian Indian-Hindu economic and political power has threatened the Fijian-Christian native population to the point of open conflict in which Hindu temples have been set alight. In the recent elections in Trinidad, Trinidadians of the Indian-Hindu hue have for the first time in history taken political control of the nation. A Trinidadian of African decent writing to me of this 
development says this:

So for the first time in history Trinidad and Tobago has an "Indian" Prime Minister ... The ascendency of an Indian to the office of Prime Minister has been a traumatic experience for Christians and Africans. For, despite the proud boast of our national anthem: "here every creed and race find an equal place", Christians and Africans have always understood themselves to be more equal than the rest ... So while Trinidad and Tobago still remains in my books the most successful experiment in religious and cultural pluralism I know of, it would be foolhardy to ignore the potential for serious trouble in the increasing tendency towards ethnic polarization exposed in the recent elections, and permit ourselves though inertia to slide into the belief that the future is bound to be like the past.

The expatriate Hinduism in the Western world has also undergone fundamental changes in the past decade. Thanks to the efforts like that of Hinduism Today, the Hindu community in the Western world is shaping itself, slowly but surely, into a conscious international religious reality much like the Christian, Jewish, and Islamic communities. To those who were watchful the signs of this development were evident at the Second Parliament of World Religions in Chicago.

What has all this meant to the HinduChristian Dialogue over the past ten years?

On the one hand, new strains have developed in relationships that were once assumed to be in good order. The other religious communities today have a new experience of Hinduism and have begun to take the Hindu reality more seriously than they had done before. On the other hand, there has arisen among the Hindu partners a new awareness of the need to watch what is happening to them as a religious community, and a new interest in the need to build bridges of understanding with neighbours of other faith traditions.

In India, many calls for dialogue encounters have been initiated by the
Hindus. The subject matters for dialogue have also moved away from "religious" topics to concerns related to reconciliation, peace, justice, nationalism, secularism, pluralism, etc. The first ever academic course on Interfaith dialogue at the University level was set up at the Madurai-Kamraj University in South India, entirely out of Hindu initiatives. In Fiji, the traumatic community relations following the political developments have led to a dialogue process called "Interfaith Search". As part of the process the WCC was asked to send in International Multifaith Team to visit with all the religious communities. In Trinidad and Tobago new Interfaith Communities have begun to meet "to create a culture of dialogue".

This does not mean that the earlier dialogue encounters and spiritual exchanges have been abandoned. The past decade, however, has brought new dimensions into this relationship.

Yet another new dimension in this area is the rise of "dalit consciousness", an expression that portrays the rise in the last decade of the articulate voice of India's much neglected "scheduled" or "depressed" classes. They have chosen to call themselves "dalits", meaning the "the broken", "the suppressed", and "the dispossessed". Placing much of the blame for their situation on classical Hinduism, the dalits have spared no energy in challenging the Christians both on the partners and the issues for dialogue. The concern raised has resulted in much intra-Christian debate and soul-searching, but has not had the effect of fundamentally affecting the ongoing dialogues. It has, however, pointed once again to the need to take full account of the complexity of the Indian religious and cultural reality.

It is the Christian willingness to recognize more fully the diversity within Hinduism, and the Hindu willingness to take more seriously the inherent and new dangers to life in community posed by the increased role of all religions in public life that are likely to further the Hindu-Christian dialogue in the coming years. 